1.

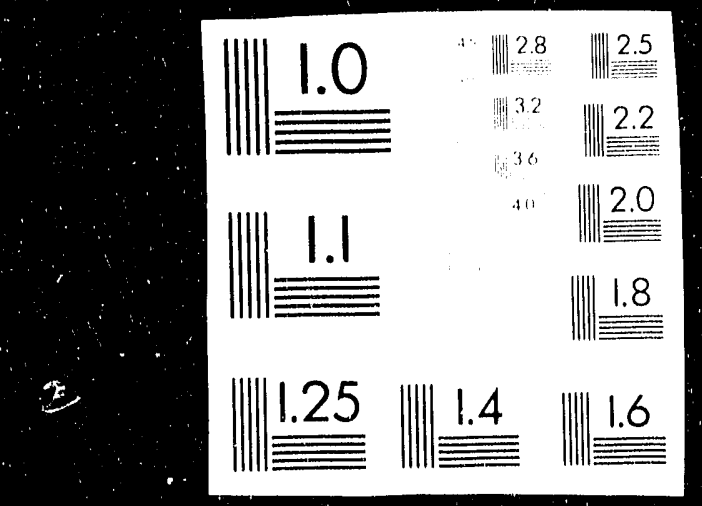

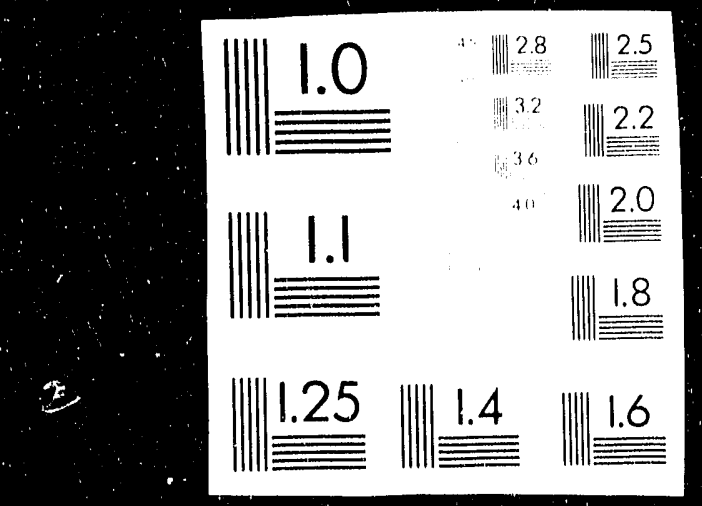

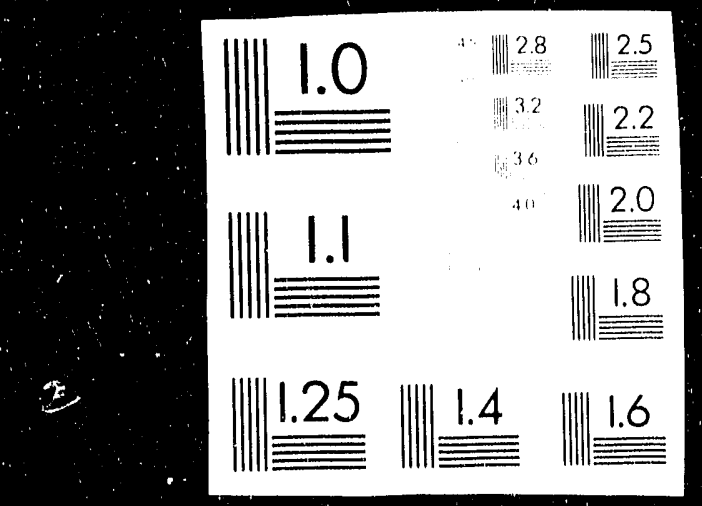

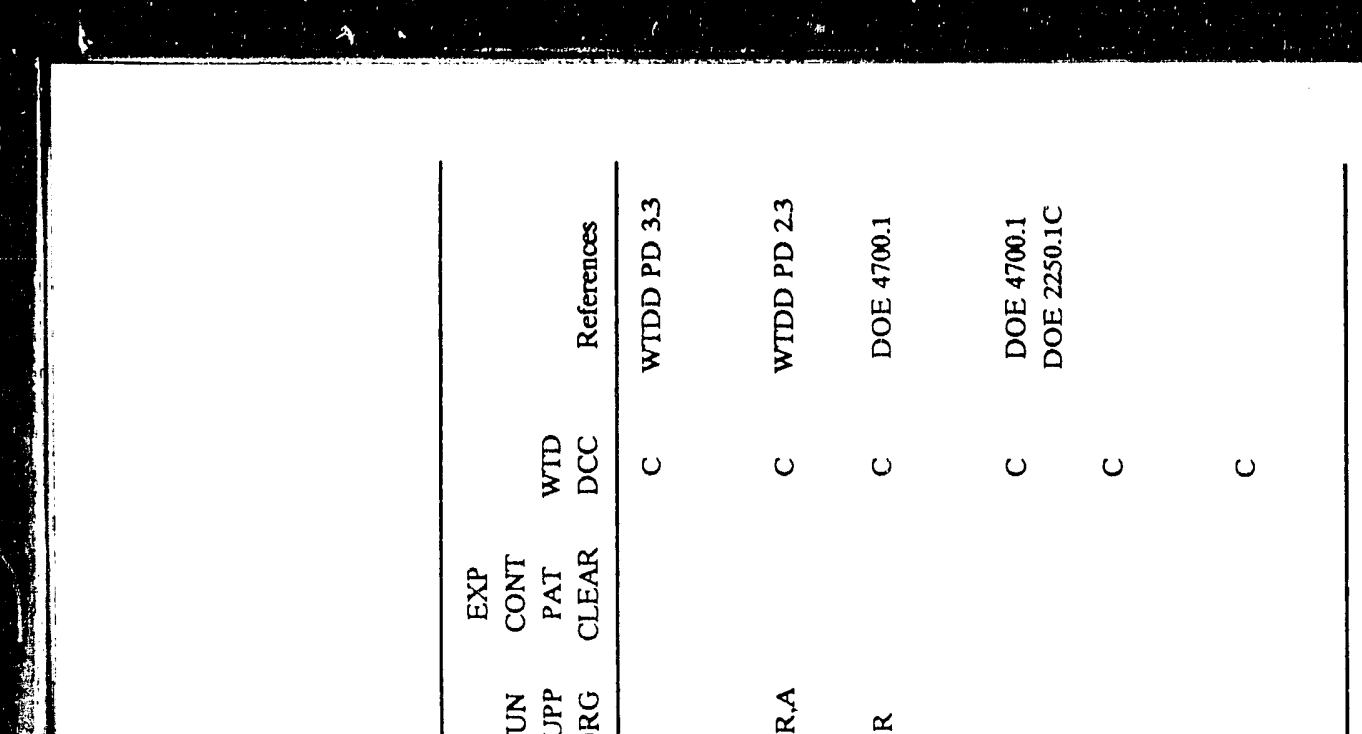




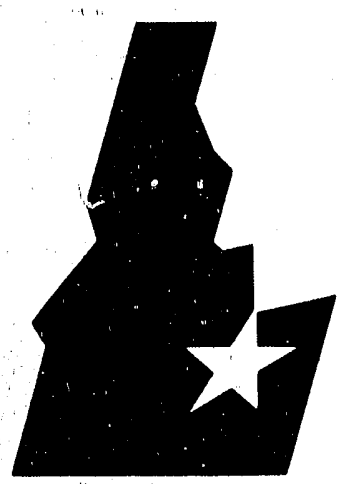

Idaho

National

Engineering

Laboratory

Managed

by the U.S.

Department

of Energy
EGG-WTD-10081

February 1992

41:2' 1992

\section{Buried Waste Integrated \\ Demonstration Configuration \\ Management Plan}

P. G. Cannon

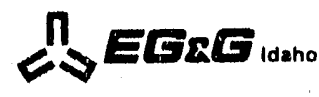

Work performed under DOE Contract No. DE-ACO7-761D01570 
This document contains new concepts or the author(s) interpretation of new calculations and/or measurements; accordingly, EG\&G Idaho, Inc. is required by the United States Government to include the following disclaimer:

\section{DISCLAIMER}

This report was prepared as an account of work sponsored by an agency of the United States Government. Neither the United States Government nor any agency thereof, nor any of their employees, makes any warranty, express or implied, or assumes any legal liability or responsibility for the exccuracy, completeness, or usefulness of any information, apparatus, product or process disclosed, or represents that its use would not infringe privately owned rights. References herein to any specific commercial product, process, or service by trade name, trademark, manufacturer, or othenwise, does not necessarily constitute or imply its endorsement, recommendation, or favoring by the United States Government or any agency thereof. The views and opinions of authors expressed herein do not necessarily state or reflect those of the United States Government or any agency thereof. 


\title{
Buried Waste Integrated Demonstration Configuration Management Plan
}

\author{
P. G. Cannon
}

Published February 1992

\author{
Idaho National Engineering Laboratory \\ EG\&G Idaho, Inc. \\ Idaho Falls, Idaho 83415
}

\author{
Prepared for the \\ U.S. Department of Energy \\ Office of Environmental Restoration and Waste Management \\ Under DOE Idaho Field Office \\ Contract DE-AC07-76ID01570
}




\section{Buried Waste Integraied Demonstration Configuration Management Plan EGG-WTD-10081}

Prepared by:

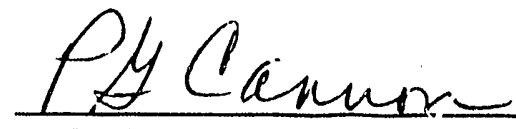

P. G. Cannon

$\frac{2-20-92}{\text { Date }}$

Reviewed and Approved by:
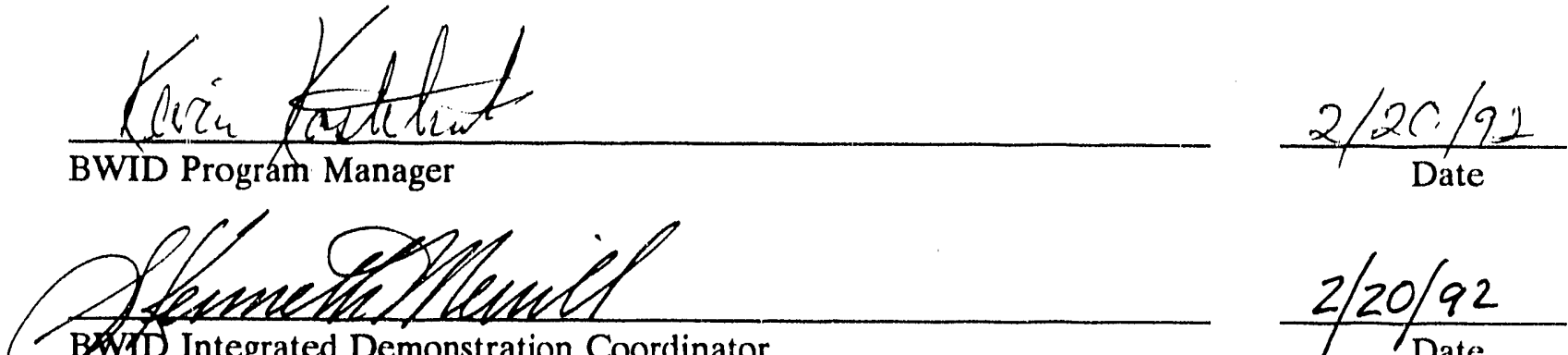

Bw1. Integrated Demonstration Coordinator

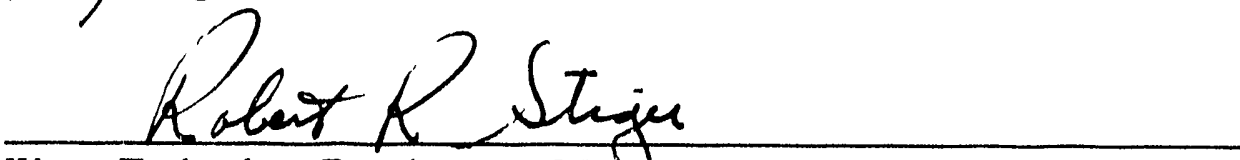

Waste Technology Development Mantuger
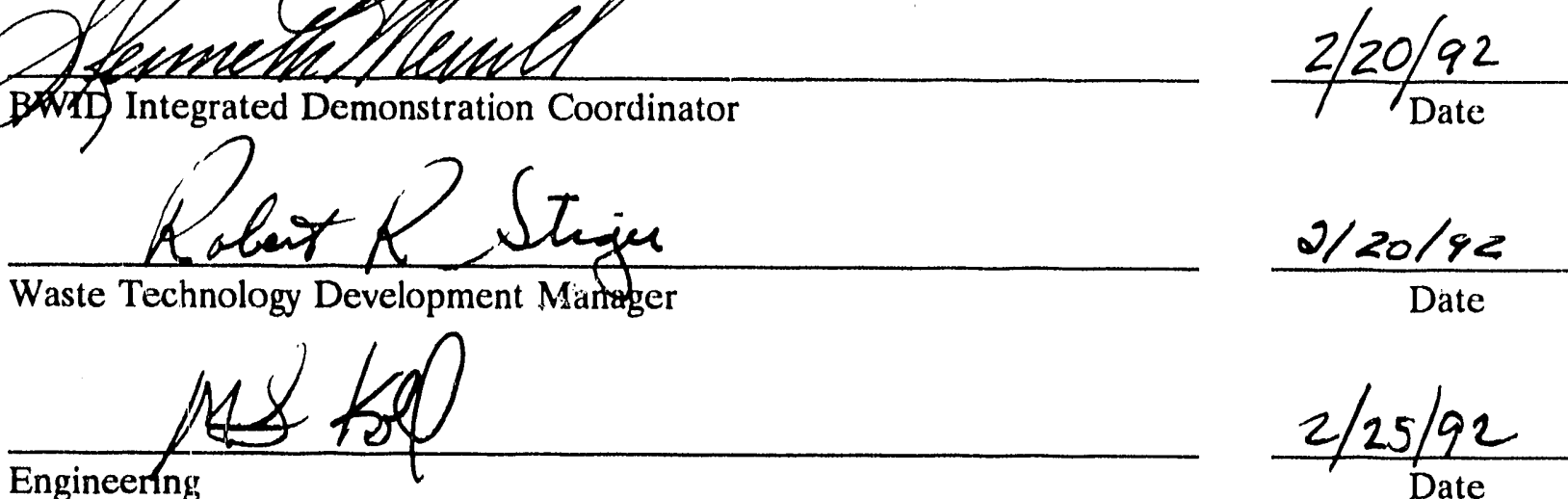

$2 / 20 / 92$

$\frac{2 / 25 / 92}{\text { Date }}$ 


\section{ABSTRACT}

This document defines plans for the configuration management requirements for the Buried Waste Integrated Demonstration (BWID) Program. Since BWID is managed programmatically by the Waste Technology Development Department (WTDD), WTDD Program Directive (PD) 1.5 (Document Preparation, Review, Approval, Publication, Management and Change Control) is to be followed for all internal EG\&G Idaho, Inc., BWID programmatic documentation. BWID documentation generated by organizations external to EG\&G Idaho is not covered by this revision of the Configuration Management Plan (CMP), but will be addressed in subsequent revisions. 


\section{CONTENTS}

ABSTRACT $\ldots \ldots \ldots \ldots \ldots \ldots \ldots \ldots \ldots \ldots \ldots \ldots \ldots \ldots \ldots \ldots \ldots \ldots \ldots$

ACRONYMS $\ldots \ldots \ldots \ldots \ldots \ldots \ldots \ldots \ldots \ldots \ldots \ldots \ldots \ldots \ldots \ldots \ldots \ldots \ldots \ldots$

1. INTRODUCTION $\ldots \ldots \ldots \ldots \ldots \ldots \ldots \ldots \ldots \ldots \ldots \ldots \ldots \ldots \ldots \ldots$

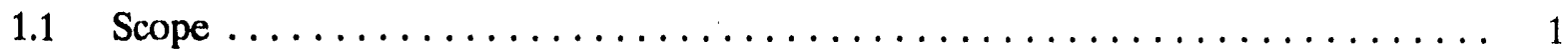

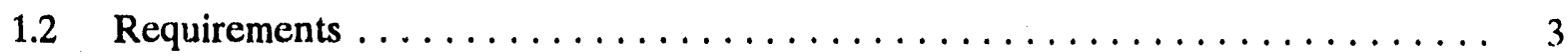

2. ORGANIZATION AND RESPONSIBILITIES $\ldots \ldots \ldots \ldots \ldots \ldots \ldots \ldots \ldots$

2.1 BWID Program Organization $\ldots \ldots \ldots \ldots \ldots \ldots \ldots \ldots \ldots \ldots \ldots \ldots$

2.2 BWID Configuration Management Organization and Responsibilities ........ 7

3. CONFIGURATION IDENTIFICATION $\ldots \ldots \ldots \ldots \ldots \ldots \ldots \ldots \ldots \ldots \ldots$

3.1 BWID Program Document $\ldots \ldots \ldots \ldots \ldots \ldots \ldots \ldots \ldots \ldots \ldots \ldots \ldots$

3.1.1 Buried Waste Integrated Demonstration Plan ............. 8

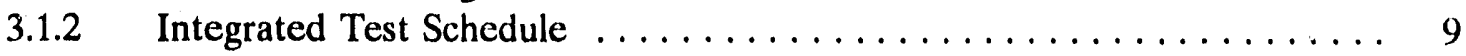

3.1.3 Preparedness and Consent Plan ................... 9

3.1.4 Regulatory Compliance Plan (RCP) Guidance $\ldots \ldots \ldots \ldots \ldots \ldots \ldots$

3.1.5 Facility Evaluation and Development Guidance $\ldots \ldots \ldots \ldots \ldots \ldots \ldots$

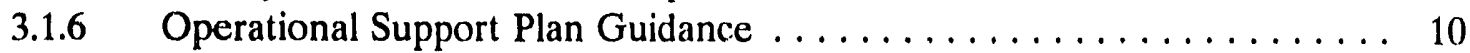

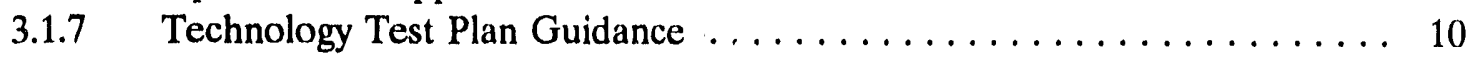

3.1.8 Buried Waste Integrated Demonstration Program Technology

Evaluation Report Guidance . . . . . . . . . . . . . . . . 10

3.1.9 Buried Waste Integrated Demonstration Program Weekly Status

Report ............................. 10

3.1.10. Technology Status Report Guidance .................. 11

4. CONFIGURATION CONTROL $\ldots \ldots \ldots \ldots \ldots \ldots \ldots \ldots \ldots \ldots \ldots \ldots \ldots$

4.1 Change Control $\ldots \ldots \ldots \ldots \ldots \ldots \ldots \ldots \ldots \ldots \ldots \ldots \ldots \ldots \ldots \ldots$

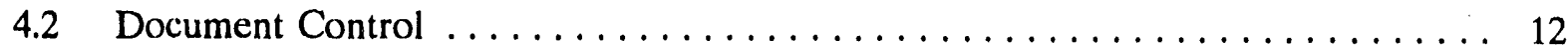

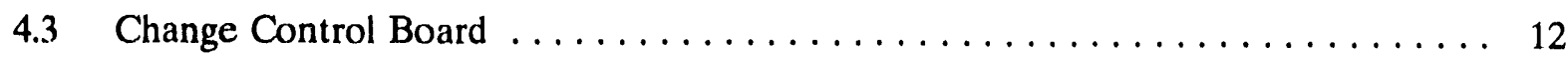

5. STATUS RECORDING AND REPORTING $\ldots \ldots \ldots \ldots \ldots \ldots \ldots \ldots \ldots \ldots$

6. CONFIGURATION VERIFICATION $\ldots \ldots \ldots \ldots \ldots \ldots \ldots \ldots \ldots \ldots \ldots \ldots$ 


\section{FIGURES}

1. Buried Waste Integrated Demonstration Project organization chart. . . . . . . . . 2

2. BWID Configuration Management organization chart. $\ldots \ldots \ldots \ldots \ldots \ldots \ldots$

3. BWID document hierarchy. $\ldots \ldots \ldots \ldots \ldots \ldots \ldots \ldots \ldots \ldots \ldots \ldots \ldots$

\section{TABLES}

1. Documents responsibility matrix $\ldots \ldots \ldots \ldots \ldots \ldots \ldots \ldots \ldots \ldots \ldots \ldots$ 


\section{ACRONYMS}

BWID

BWP

BWPM

CCB

CMP

CSG

DOE

DOE-HQ

DOE-ID

ERP

IDC

IDPM

INEL

MWLID

OTD

PD

PI

QPP

R\&D

SAR

TPM

TPO

TSG

TSR

TTP

WTDD

WTDD DC
Buried Waste Integrated Demonstration

Ruried Waste Program

Buried Waste Program Manager

Change Control Board

Configuration Management Plan

Core Support Group

Department of Energy

Department of Energy-Headquarters

Department of Energy Idaho Field Office

Environmental Restoration Program

Integrated Demonstration Coordinator

Integrated Demonstration Program Manager

Idaho National Engineering Laboratory

Mixed Waste Landfill Integrated Demonstration

Office of Technology Development

Program Directive

Principal Investigator

Quality Program Plan

Research \& Development

Safety Analysis Report

Technical Program Manager

Technical Program Officer

Technical Support Group

Technology Status Report

Technical Task Plan

Waste Technology Development Department

Waste Technology Development Department Document Control 


\section{Buried Waste Integrated Demonstration Configuration Management Plan}

\section{INTRODUCTION}

This Configuration Management Plan (CMP) establishes requirements for the configuration management system for the Buried Waste Integrated Demonstration (BWID) Program. This CMP is consistent with and responsive to the U.S. Department of Energy (DOE) Order 4700.1, DOE Idaho Field Office (DOE-ID) Order ID 4700.1, and the Waste Technology Development Department (WTDD) Program Directive (PD), WTDD PD 3.3.

Configuration management provides systems by which design and program requirements are identified, controlled, and reported.

The BWID configuration management system shall focus on the following activities:

- Configuration Identification-The process of designating the baseline configuration items that will come under configuration control.

- $\quad$ Configuration Control-The process of managing and controlling changes to the baseline configuration items to ensure that changes are adequately defined, evaluated, reviewed, approved, and implemented.

- Status Recording and Reporting-The process of recording and reporting the current status of the configuration items and the associated documentation, including the status of all proposed and approved changes to those items.

- Configuration Verification-The process of verifying that all configuration items have been produced, that the current configuration agrees with specified requirements and associated documentation, and that all change requests have been resolved.

Management of the BWID Program is defined in Section 2 of this Plan. The BWID Program Manager is responsible to ensure configuration requirements are met.

\subsection{Scope}

As indicated by the organization chart in Figure 1, BWID-funded activities are performed by numerous organizations both internal and external to EG\&G Idaho, Inc. Several required documents are only in the conceptual stages (e.g., Preparedness and Consent Plan), while many others are well defined (e.g., WTDD Program Directives). Therefore, this CMP will only apply to BWID documents prepared and controlled within WTDD.

As the program matures, this scope will be expanded to include internal documents within EG\&G Idaho followed by documents external to EG\&G Idaho (c.g., other DOE sites, universities, industry). 


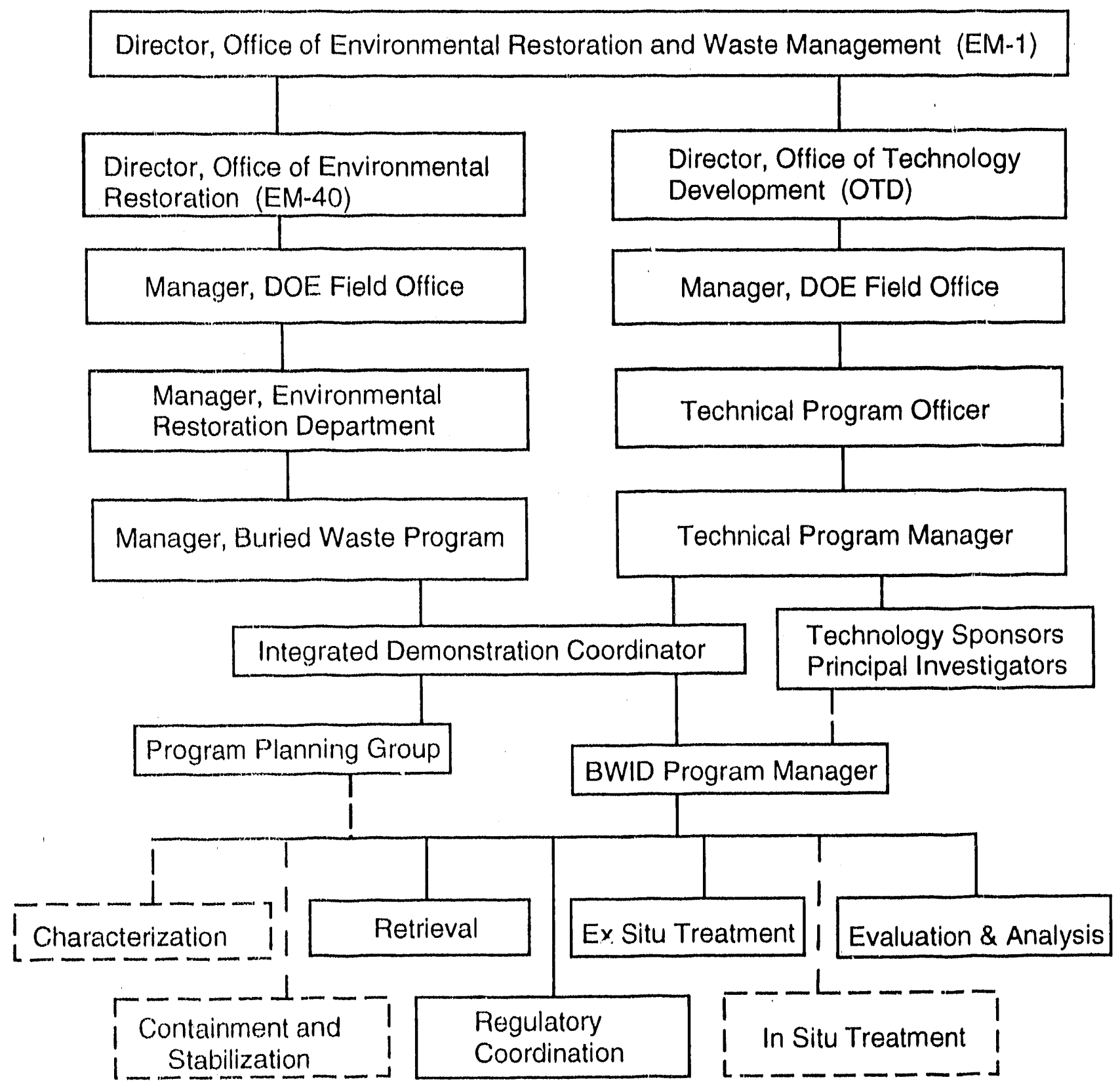

BWID TSGs only

- $-\ldots$ BWID/MWLID Joint TSGs

Figure 1. Buried Waste Integrated Demonstration Project organization chart. 
Also, as demonstrations are scheduled, this CMP will be revised to include Interface Agreements between the applicable facility's Tenants Manual and BWID documents. The affected facility managers concurrence will be obtained on the revised CMP.

Principal Investigators external to EG\&G Idaho will be required to provide evidence of configuration managements systems which support activities funded by BWID.

\subsection{Requirements}

All applicable BWID documents will be prepared, reviewed, approved, published, managed, and revised per WTDD Program Directive (PD) 1.5, Document Preparation, Review Approval, Publication, Management and Change Control. To determine applicability, refer to Appendix A of WTDD PD 1.5 for a list of documents and Figure 2 in this document.

BWID document generators will reference higher tier documents (see Table 1) to ensure compliance to applicable requirements and consistency of information when redundancy is required. 


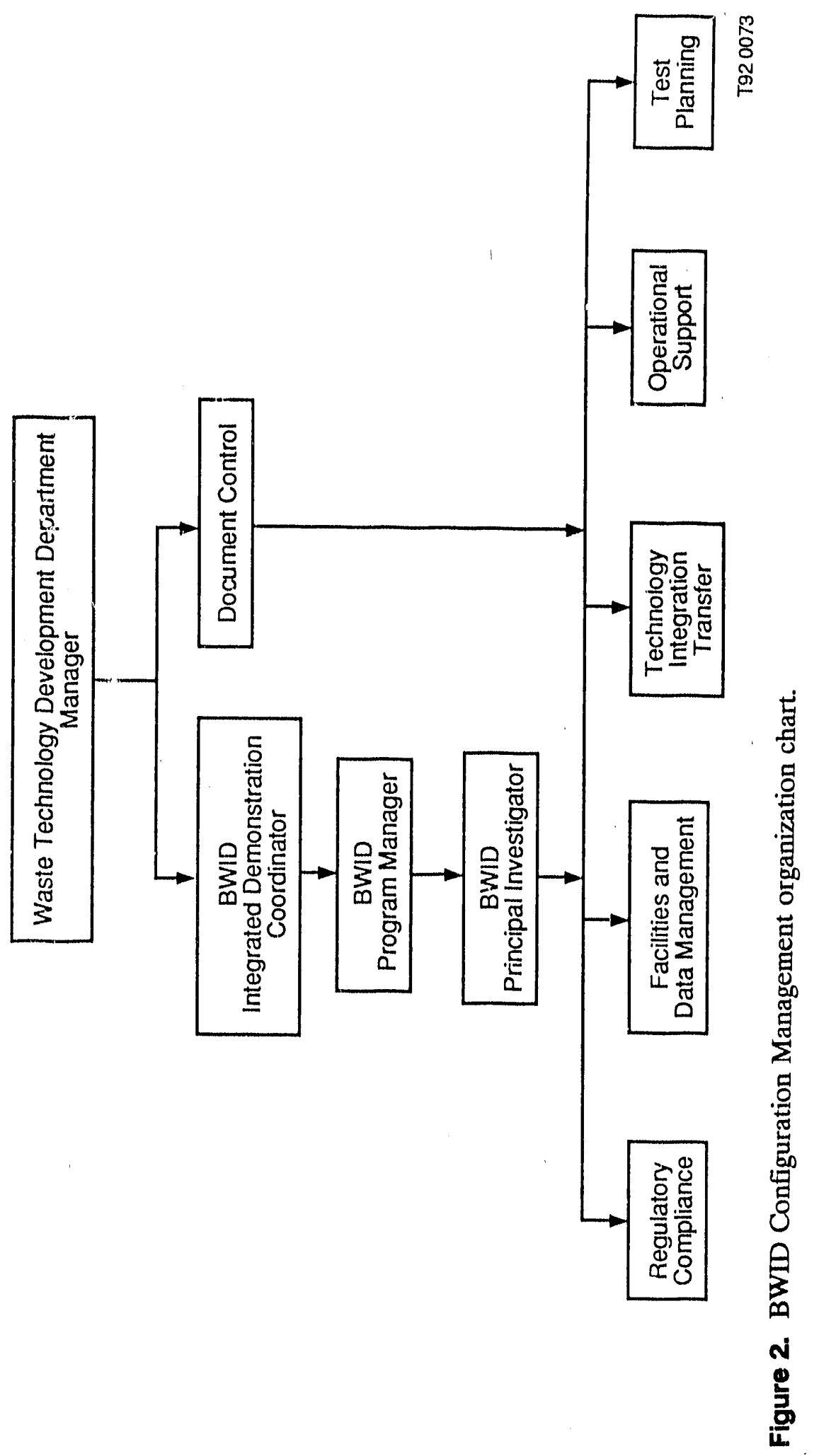




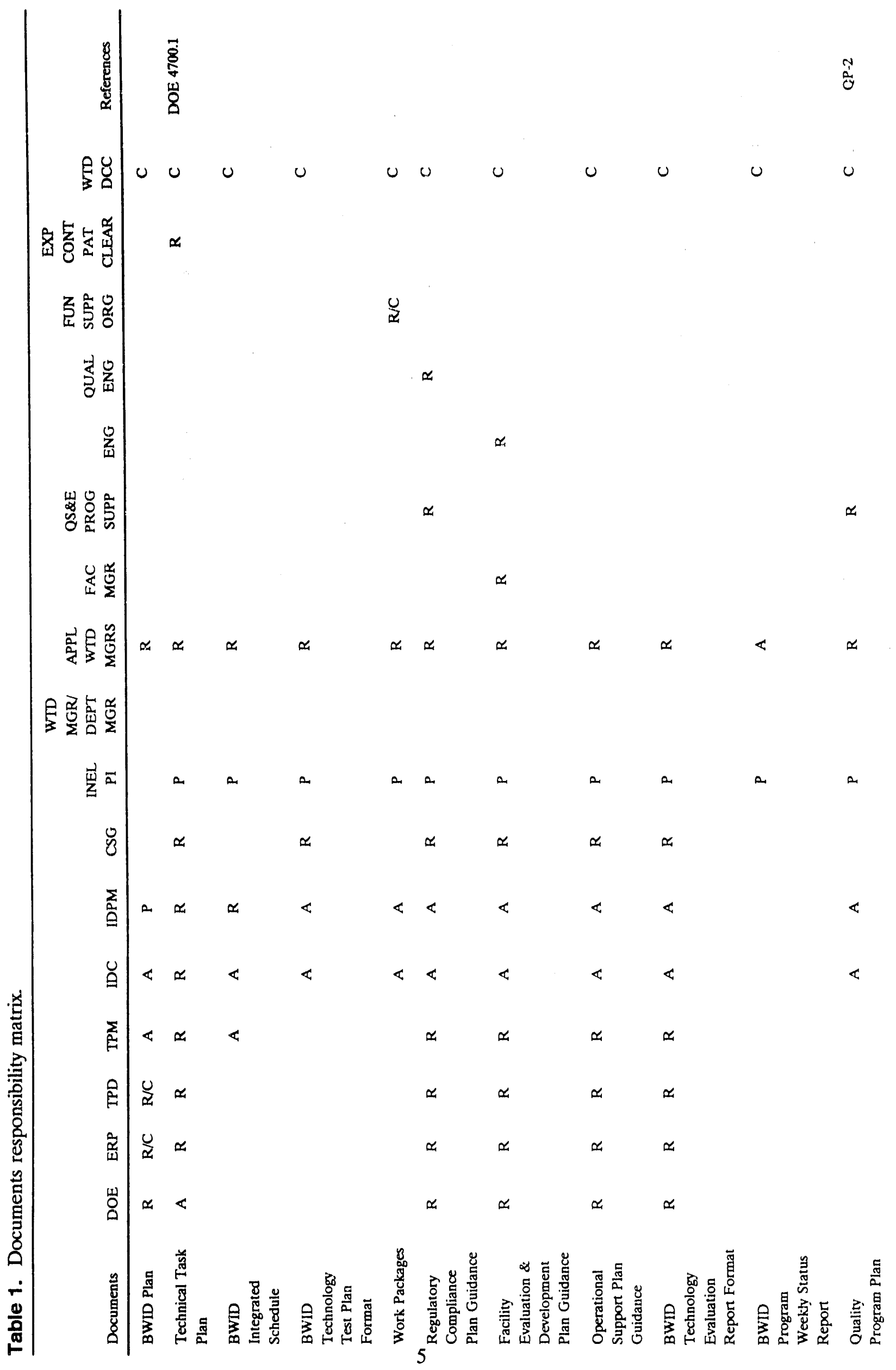




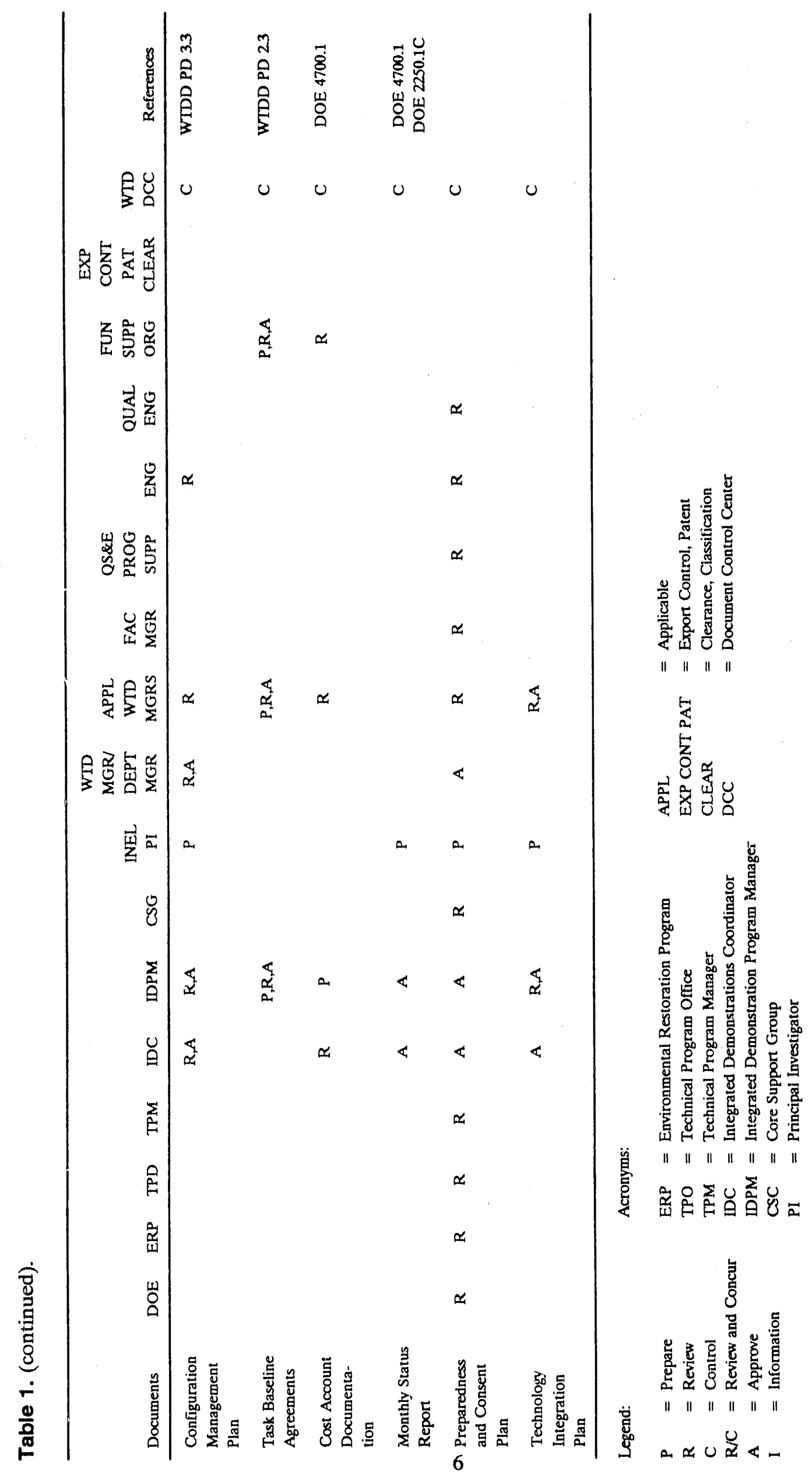




\section{ORGANIZATION AND RESPONSIBILITIES}

\subsection{BWID Program Organization}

BWID is a DOE program with a mission to develop a comprchensive, synergistic system comprised of technologies which are faster, better, safer, and cheaper than the current state-of-the-art for the remediation of DOE complex-wide buried waste. The INEL has been designated as the host site and has responsibility to not only manage the program, but will also be the site of many of the demonstrations. Participants in the BWID Program come from private industries, universities, and all of the DOE complex sites. Relationships between all of these parties is represented by the organization chart shown in Figure 1. A discussion of responsibilities can be found in the Buried Waste Integrated Demonstration Plan, EGG-WTD-9870.

\subsection{BWID Configuration Management Organization and Responsibilities}

The organization charc for BWID configuration management is presented in Figure 2. activities.

The BWID Program Manager has primary responsibility for BWID configuration management

Document generators are responsible for compliance to requirements outlined in this CMP and WTDD PD 1.5. 


\section{CONFIGURATION IDENTIFICATION}

\subsection{BWID Program Document}

A generic list of documents requiring control appear in WTDD PD 1.5, Appendix A. Documents from this list, which are applicable to BWID, have been listed below for convenience. Also listed below are documents which have been created to support specific BWID management needs. These documents also require control.

\section{BWID Specific Documents}

Buried Waste Integrated Demonstration Plan

Integrated Test Schedule

Preparedness and Consent Plan Guidance

Regulatory Compliance Plan Guidance

Facility Evaluation and Development Plan Guidance

Operational Support Plan Guidance

Technology Test Plan Guidance

Buried Waste Integrated Demonstration Program Technology Evaluation Report Guidance

Buried Waste Integrated Demonstration Program Weekly Status Report

Technology Status Report Guidance

Generic BWID Documents (refer to WTDD PD 1.5, Appendix A)

Work Packages

Technical Task Plans

Quality Program Plan

Configuration Management Plan

Task Baseline Agreements

Cost Account Documentation

Monthly Status Report

A discussion of BWID specific documents follows.

\subsubsection{Buried Waste Integrated Demonstration Plan}

This is a program-level document which establishes the foundation for the BWID Program. This document describes strategies, organization roles, responsibilities and interfaces, and management processes to be used by the program staff to accomplish the BWID mission, objectives, and goal. The audience for this document is all BWID participants.

The BWID Program Manager is responsible for the preparation of the document. 


\subsubsection{Integrated Test Schedule}

schedules.

The purpose of this document is to integrate BWID schedules with other BWID related

The audience for this document is all BWID participants.

The BWID Program Manager is responsible for the preparation of this document.

\subsubsection{Preparedness and Consent Plan}

This document was created to provide the Principal Investigators (PI) with a road map for early demonstration planning. It is a document designed to help the PI prevent problems which could significantly delay demonstrations. The document will contain planning tools such as checklists and decision matrices, which will be completed by the PI with support from the BWID staff. Responses from the PIs will result in "contracts," (in some instances) between the PI, BWID support staff, and the host facility management which document agreed upon responsibilities for the accomplishment of tasks, acquisition of resources, and preparation of compliance documentation (e.g., requests for permits, procedures, implementation plans, reports, etc.). Other responses may only result in a "needs list" required by a support function to prepare for a demonstration. This document will consist of four sections, e.g., Regulatory Compliance, Facility Evaluation and Development, Operations Support and Test Planning. Until the Preparedness and Consent Plan concept is finalized, guidance documents for each of these sections will be produced as separate documents. The primary audience for this document is the PIs, BWID support staff, and management.

The PI for the BWID TTP has primary responsibility for the preparation of this document. The Program Managers for Facility/Engineering Support, Operations Support, and Test Planning also share in this responsibility.

\subsubsection{Regulatory Compliance Plan (RCP) Guidance}

This document will guide the PI through the development of a plan which will help the PI comply with Environmental, Safety, Health and Quality (ESH\&Q) requirements that pertain to their tasks. The RCP will contain the following:

- What sources of requirements are applicable to that task?

- Who will be responsible for complying with the requirements in each source?

- $\quad$ How will compliance be accomplished?

- When is the action to be accomplished?

The PI will be the primary audience for this document.

The PI for the BWID TTP has primary responsibility for the preparation of this document. 


\subsubsection{Faclity Evaluation and Development Guidance}

This document will provide the I Is with a facility requirements checklists. Responses from the PIs will provide the BWID facilities staff with information concerning facilities, utilities, and data management needs. The primary audience for this document is the PIs.

The Program Manager for Facilities and Data Management has primary responsibility for the preparation of this document.

\subsubsection{Operational Support Plan Guidance}

This document will provide the PIs with an operational support checklist. Responses from the PIs will provide the BWID Operations staff with information concerning the support needed in determining the degree of operational readiness for each demonstration scheduled to be conducted at the INEL. The PI will be the primary audience for this document.

The PI for the BWID TTP has primary responsibility for the preparation of this document.

\subsubsection{Technology Test Plan Guidance}

This document will provide the PI with criteria for the development of technology demonstration test plans. The PI will be the primary audience for this document.

The PI for the BWID TTP has primary responsibility for the preparation of this document.

\subsubsection{Burled Waste Integrated Demonstration Program Technology Evaiuation Report Guidance}

This document will provide the PI with criteria for the preparation of a Technology Evaluation Report, which will be used by BWID Program management to evaluate the technology based on the demonstration. The PI will be the primary audience for this document.

The BWID Program Manager has primary responsibility for the preparation of this document.

\subsubsection{Buried Waste Integrated Demonstration Program Weekly Status Report}

This report provides an overall summary of all BWID activities. This includes accomplishments, significant problems/issues and actions taken, upcoming import meetings/visits, travel experienced, and upcoming travel/visits. BWID management and staff is the primary audience for this report.

The PI for the BWID TTP has primary responsibility for the preparation of this report. All BWID managers are required to provide information for this report. 


\subsubsection{Technology Status Report Guldance}

This document will provide the PI with criteria for the development of Technology Status Reports. These reports summarize the PIs knowledge of the maturity of the technology, the readiness of the technology for demonstration, the capability of a technology to satisfy identified needs, requirements of a technology for demonstration, and potential benefits. The PIs will be the primary audience for this document.

The PI for the BWID TTP has primary responsibility for the preparation of this document. 


\section{CONFIGURATION CONTROL}

\subsection{Change Control}

All changes to BWID documentation will be defined, evaluated, reviewed, approved, and implemented per WTDD PD 1.5, Section 5.6. The BWID Program Manager will sign all Document Revision Requests (DRR) as the immediate manager.

Responsibility and authority for the review and approval of changes is indicated in the Documents Responsibility Matrix in Table 1.

\subsection{Document Control}

A document hierarchy showing the relationship between customer requirements, EG\&G Idaho company documents, and BWID documents is presented in Figure 3. This tree should be used when generating and reviewing documents to ensure that requirements outlined in controlling documents or higher tier documents are met.

\subsection{Change Control Board}

Changes to cost, schedule, and scope of work will be controlled through the use of a Change Control Board (CCB).

The CCB for changes within WTDD has been established by a draft WTDD Program Management Plan, WTDD PD 2.3, and the DOE-ID Program Plan. 


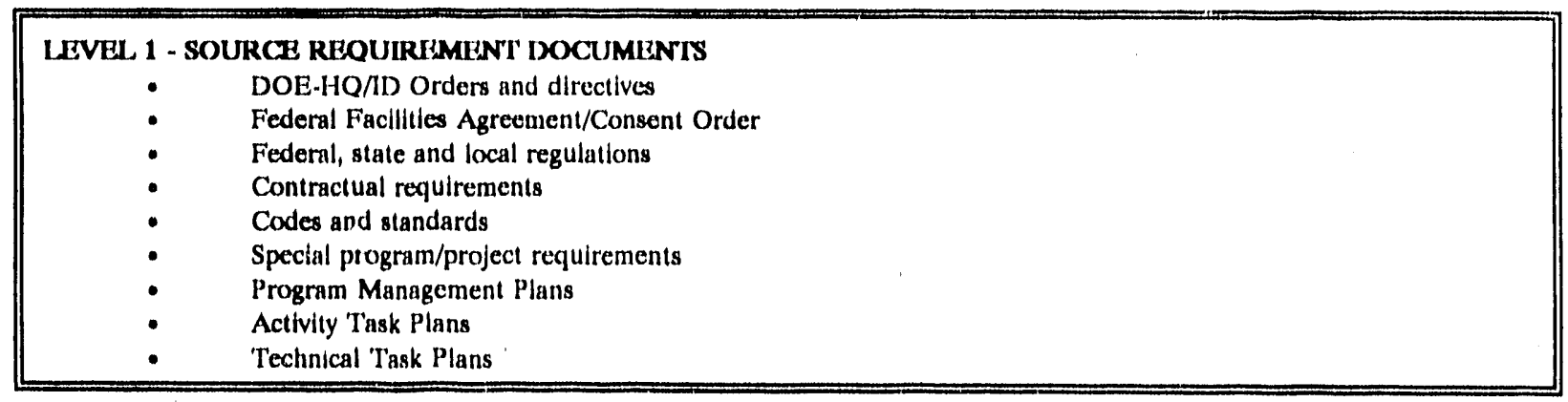

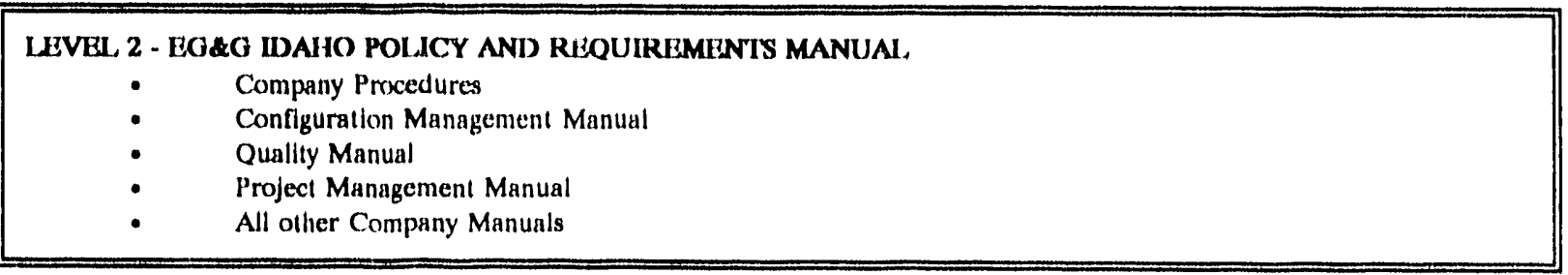

\begin{tabular}{|c|c|}
\hline $\begin{array}{r}\text { LEVIJL } 3 \\
\bullet \\
\end{array}$ & $\begin{array}{l}\text { NNINO DOCUMENIS AND SPECIFICA'ITONS } \\
\text { WTDD Program Management Plan (draft) } \\
\text { WTDD Qually Program Plan } \\
\text { WIDD Five Year Operational Plan }\end{array}$ \\
\hline
\end{tabular}

\begin{tabular}{|l} 
LEVIL, 4 - IMPLEMENTING INSIRUCITONS \\
WTDD Directives \\
COst Account Authorizations
\end{tabular}

\begin{tabular}{|c|c|}
\hline LEVEL: & 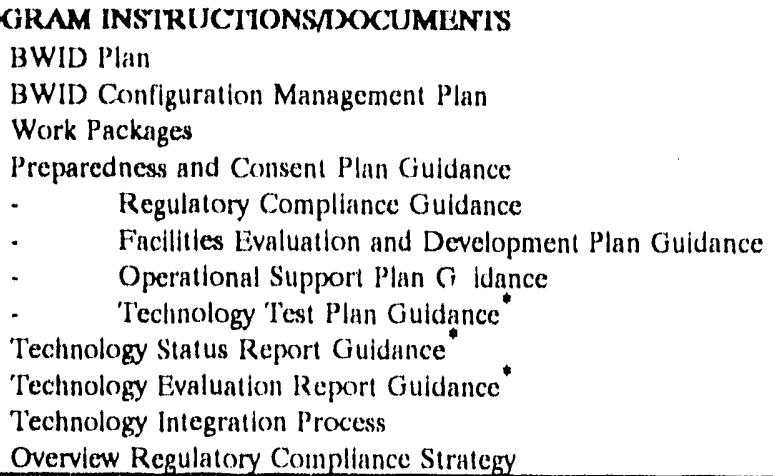 \\
\hline
\end{tabular}

\section{WORKING DOCUMENIS (PI ANS, SCHIZDUILS, ROADMAPS EIC)}

- Preparedness and Consent Plan "

- Regulatory Compliance Plan

- Facilitles Evaluation and Development Plan

- Operational Support Plan

- Integrated Test Schedule

- Resulting documents prepared by $\mathrm{Pl}$, therefore not shown.

* Prepared by BWID staff with input from PI.

Figure 3. BWID document hierarchy. 


\section{STATUS RECORDING AND REPORTING}

WTDD Document Control (DC) will collect, store, and maintain all WTDD BWID documentation per WTDD PD 1.5. Reports of current document status will be obtained from WTDD DC by the BWID Program Manager to verify document status. 


\section{CONFIGURATION VERIFICATION}

WTDD activities have been designed as Quality Level B and, as such, are audited biannually by Performance Oversighi and Assessment (PO\&S). Also, internal self-assessment surveillances are performed per the guidance outlined in WTDD PD 1.9, Self-Assessment Surveillance Program and Deficiency Tracking. Since BWID is a major WTDD program, this configuration management system will be evaluated in part by PO\&S and WTDD management. 


\section{BIBLIOGRAPHY}

Buried Waste Integrated Demonstration Plan, EGG-WTD-9870, Section 10, "Configuration Management and Change Control."

Waste Technology Development Department Program Directive, WTDD PD 3.3,

"Configuration Management."

Waste Technology Development Department Program Directive, WTDD PD 1.5, "Document Preparation, Review, Approval, Publication, Management and Change Control."

EG\&G Idaho, Inc., Resource Manual, Section 10.

EG\&G Idaho, Inc., Company Procedures Manual, Section 20.23, Configuration Management. 

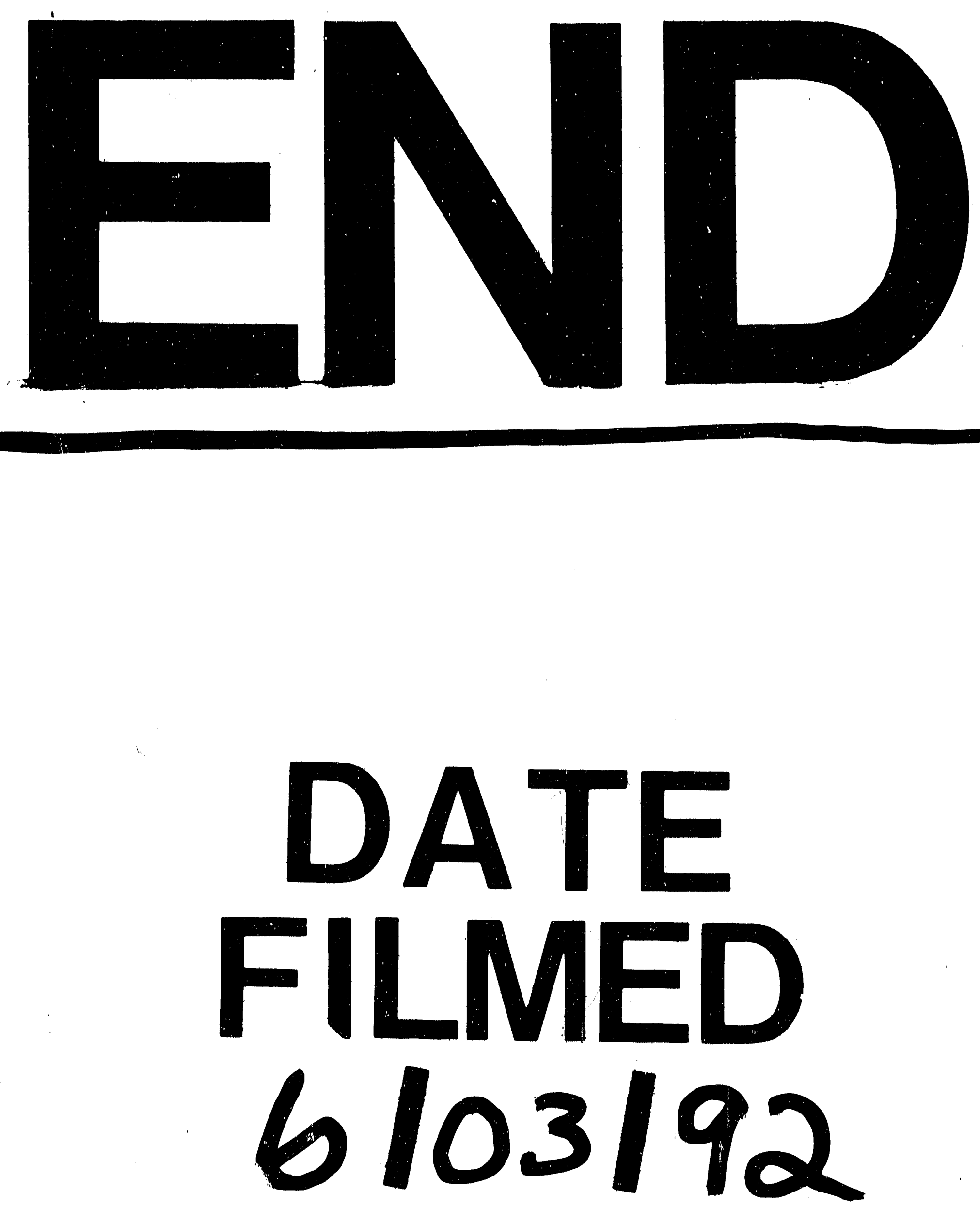


\footnotetext{
m
} 